\title{
Metabonomics-based analysis of Brachyspira pilosicoli's response to tiamulin reveals metabolic activity despite significant growth inhibition
}

Article

Accepted Version

Creative Commons: Attribution-Noncommercial-No Derivative Works 4.0

Le Roy, C. I., Passey, J. L., Woodward, M. J., La Ragione, R. M. and Claus, S. P. (2017) Metabonomics-based analysis of Brachyspira pilosicoli's response to tiamulin reveals metabolic activity despite significant growth inhibition. Anaerobe, 45. pp. 71-77. ISSN 1075-9964 doi:

https://doi.org/10.1016/j.anaerobe.2017.03.018 Available at https://centaur.reading.ac.uk/70003/

It is advisable to refer to the publisher's version if you intend to cite from the work. See Guidance on citing.

Published version at: http://www.sciencedirect.com/science/article/pii/S1075996417300677

To link to this article DOI: http://dx.doi.org/10.1016/j.anaerobe.2017.03.018

Publisher: Elsevier

All outputs in CentAUR are protected by Intellectual Property Rights law, including copyright law. Copyright and IPR is retained by the creators or other copyright holders. Terms and conditions for use of this material are defined in the End User Agreement. 


\section{www.reading.ac.uk/centaur}

\section{CentAUR}

Central Archive at the University of Reading

Reading's research outputs online 
1 Metabonomics-based analysis of Brachyspira pilosicoli's response to

\section{inhibition.}

4 Caroline Ivanne Le Roya, , Jade Louise Passeyc, Martin John Woodwarda, Roberto 5 Marcello La Ragionec, Sandrine Paule Claus ${ }^{a}$.

6

7 a Department of Food and Nutritional Sciences, University of Reading, Whiteknights,

8 Reading, UK6 6AP, UK

9 Present address ${ }^{\text {b }}$ Department of Twin Research \& Genetic Epidemiology, King's College 10 London, London SE1 7EH, UK

11 c Faculty of Health and Medical Sciences, School of Veterinary Medicine, University of 12 Surrey, Guilford, Surrey GU2 7XH, UK

13 \# Corresponding author: s.p.claus@reading.ac.uk, Tel +44 1183788717

14

15 Key words: Metabonomics, Brachyspira pilosicoli, Tiamulin, Antibiotics.

\section{Abstract}

18 Pathogenic anaerobes Brachyspira spp. are responsible for an increasing number of

19 Intestinal Spirochaetosis (IS) cases in livestock against which few approved treatments 20 are available. Tiamulin is used to treat swine dysentery caused by Brachyspira spp. and 21 recently has been used to handle avian intestinal spirochaetosis (AIS). The therapeutic 22 dose used in chickens requires further evaluation since cases of bacterial resistance to 23 tiamulin have been reported. In this study, we evaluated the impact of tiamulin at 24 varying concentrations on the metabolism of B. pilosicoli using a ${ }^{1} \mathrm{H}-\mathrm{NMR}$-based 
25 metabonomics approach allowing the capture of the overall bacterial metabolic

26 response to antibiotic treatment. Based on growth curve studies, tiamulin impacted

27 bacterial growth even at very low concentration $(0.008 \mu \mathrm{g} / \mathrm{ml})$ although its metabolic

28 activity was barely affected $72 \mathrm{~h}$ post exposure to antibiotic treatment. Only the highest 29 dose of tiamulin tested $(0.250 \mu \mathrm{g} / \mathrm{ml})$ caused a major metabolic shift. Results showed 30 that below this concentration, bacteria could maintain a normal metabolic trajectory 31 despite significant growth inhibition by the antibiotic, which may contribute to disease 32 reemergence post antibiotic treatment. Indeed, we confirmed that B. pilosicoli remained 33 viable even after exposition to the highest antibiotic dose. This paper stresses the need 34 to ensure new evaluation of bacterial viability post bacteriostatic exposure such as 35 tiamulin to guarantee treatment efficacy and decrease antibiotic resistance 36 development.

Highlight

- B. pilosicoli metabolism was characterized using ${ }^{1} \mathrm{H}$ NMR-based metabonomics

- Tiamulin inhibited B. pilosicoli growth at very low dose (respectively $<0.016$ $\mu \mathrm{g} / \mathrm{mL}$ and $>0.032 \mu \mathrm{g} / \mathrm{mL})$

- B. pilosicoli metabolism is not inhibited for tiamulin concentration superior to $0.032 \mu \mathrm{g} / \mathrm{mL}$

- B. pilosicoli metabolism is completely repressed at $0.250 \mu \mathrm{g} / \mathrm{mL}$, but remain viable

1. Introduction

47 Brachyspira pilosicoli is a gram-negative bacterium of the Spirochaetes family. It colonizes the lower part of the gastrointestinal track of a large range of hosts including 
49 pigs, birds, humans, monkeys, dogs and horses [1-4]. Once in the intestinal lumen, the bacterium is attracted via chemotaxis to the mucin barrier $[5,6]$ through which it swims mediated by its unique "corkscrew" shape and rotation of its periplasmic flagella [7]

52 aided by the secretion of mucine degrading enzymes [5,8]. B. pilosicoli attaches to the enterocytes in an end on fashion and may also infect these cells [9-12]. Colonization by B. pilosicoli can lead to the development of intestinal spirochaetosis (IS), the signs of which are diarrhea, poor overall condition, dehydration and decreased growth rate. Mortality is often significant when the disease is left untreated [13-15], a consequence that makes IS a serious economic and welfare problem in farming.

Tiamulin is effective in treating IS caused by Brachyspira hyodystenteriae, B. hampsonii and B. pilosicoli in swine [16-18] and in poultry [19-21]. Tiamulin is a bacteriostatic derived from a natural pleuromutilin that binds the $50 \mathrm{~S}$ region of the ribosome to inhibit protein synthesis [22]. The antibiotic blocks peptide bond formation by interfering with substrate binding [22-25]. Tiamulin treatment in farms generally results in clearance of infection and associated symptoms. However, reoccurrence of the disease can be observed post treatment indicating incomplete clearance and possibly decreased susceptibility $[26,27]$ in response to treatment. The reason may be an inappropriate dosing as there is currently there is a lack of an internationally recognized standardized method to determine tiamulin minimum inhibitory concentration (MIC) for this bacterium, which has impacts upon selection of an appropriate treatment dose. Furthermore, recent studies have indicated that

70 Brachyspira may acquire resistance against tiamulin and, other than blocking protein synthesis, nothing is yet known of the metabolic response of B. pilosicoli to tiamulin. We

72 argue that evaluating this using a metabonomics approach would allow a better 
73 understanding of the bacterial response to tiamulin and give insights into improving

74 selection of effective dosing regimes.

75 Metabonomics allows non-targeted evaluation of the metabolic modifications occurring 76 in a biological system in response to a stress [28], which in this study is exposure to 77 tiamulin. By providing a general overview of the metabolic response, this technique 78 allows the generation of new hypotheses and to evaluate metabolic in response to environmental stress or genetic modification. In this study, we used an NMR-based metabonomics approach coupled with multivariate statistics to evaluate the metabolic dose-response of $B$. pilosicoli to tiamulin. Bacteria were exposed to gradual antibiotic doses and media were sampled over $120 \mathrm{~h}$ in order to evaluate the evolution of its metabolic composition during growth. This allowed to snapshot the metabolic response of $B$. pilosicoli to tiamulin.

\section{Material and Methods}

\subsection{Bacterial growth and antibiotic assay}

B. pilosicoli B2904 isolated from chicken presenting clinical signs of AIS in the UK [29] were grown from frozen stock on agar solidified BEB plate for four days under anaerobic conditions $\left(94 \% \mathrm{~N}_{2}\right.$ and $\left.6 \% \mathrm{CO}_{2}\right)$ at $37^{\circ} \mathrm{C}$. Colonies were transferred into Brachyspira enrichment broth media (BEB supplemented with heart infusion) for three days under similar conditions. The bacterial concentration was then adjusted in BEB to $1 \times 10^{6} \mathrm{CFU} / \mathrm{ml}$ and transferred into 24 well plates (2 $\mathrm{ml}$ per well) and incubated as

94 above for $120 \mathrm{~h}$. Every $24 \mathrm{~h}$ (with a first time point at $0 \mathrm{~h}$ growth), the entire well content was taken and centrifuged for $2 \mathrm{~min}$ at $2400 \mathrm{~g}$ to separate growth medium from bacteria. The supernatant was kept at $-80^{\circ} \mathrm{C}$ for further analysis. This process was 
97 repeated at each time point in sextuplet to deliver the appropriate power for statistical analysis.

99 The same method was used for the tiamulin assay. Bacterial cells were grown as above 100 and bacterial pellets were resuspended in BEB with antibiotic at six concentrations $101(0.008,0.016,0.031,0.062,0.125$ and $0.250 \mu \mathrm{g} / \mathrm{ml}$ plus control). Bacteria were then 102 inoculated into 24 well plates as previously described and incubated for $120 \mathrm{~h}$. For 103 metabolic analysis, each condition (tiamulin concentration) and time point (every $24 \mathrm{~h}$ 104 for $120 \mathrm{~h}$ ) were also repeated in sextuplet. The medium was not changed for the 105 duration of the experiment so that antibiotic exposure was continuous.

106 To evaluate the viability of B. pilosicoli post- antibiotic exposure, the above experiment 107 was repeated in triplicate. Following $120 \mathrm{~h}$ incubation, B. pilosicoli was inoculated onto 108 fastidious anaerobic blood agar and incubated at $37^{\circ} \mathrm{C}$, anaerobically for $48 \mathrm{~h}$. Following 109 incubation all plates were visually inspected for bacterial growth.

110 B. pilosicoli growth was evaluated using the same experimental design as the one 111 previously described. Bacteria were grown in a 96 well plate $(0.2 \mathrm{ml}$ per well) and 112 bacterial growth was evaluated every $2 \mathrm{~h}$ for $120 \mathrm{~h}$ at an absorbance of $600 \mathrm{~nm}$ using a

113 Fluostar (Info). Water was used as blank and broth media without bacteria as a negative 114 control. Each condition (tiamulin concentration) was repeated in triplicate and results 115 are presented as an average of the log of the bacterial concentration calculated from the 116 absorbance observed at each tiamulin concentration per time point after correction 117 with standard curve.

\subsection{NMR spectroscopy}

120 For NMR spectroscopy, $0.4 \mathrm{ml}$ of media was added to $0.2 \mathrm{ml}$ of NMR phosphate buffer 121 (made in $\mathrm{D}_{2} \mathrm{O}$ containing $10 \%$ water and $0.05 \%$ sodium 3-(tri-methylsilyl) propionate- 
122 2,2,3,3- $\mathrm{d}_{4}$ (TSP) as a ${ }^{1} \mathrm{H}$ NMR reference) and $0.5 \mathrm{ml}$ of the solution was transferred into

$1235 \mathrm{~mm}$ of outer diameter NMR tubes. ${ }^{1} \mathrm{H}-\mathrm{NMR}$ spectra were acquired on a Bruker Avance

124 DRX 700 MHz NMR Spectrometer (Bruker Biopsin, Rheinstetten, Germany) operating at

$125700.19 \mathrm{MHz}$ and equipped with a cryogenic probe from the same manufacturer. A

126 standard 1-dimensional (1D) pulse sequence [recycle delay (RD)- $90^{\circ}-t 1-90^{\circ}-t m-90^{\circ}$ -

127 acquire free induction decay (FID)] with water suppression applied during RD of $2 \mathrm{~s}$

128 and a mixing time $(\mathrm{tm})$ of $100 \mathrm{~ms}$ and a $90^{\circ}$ pulse set at $10 \mu \mathrm{s}$ was applied. For each

129 spectrum 128 scans were recorded on a total of $32 \mathrm{~K}$ data points. A broadening line

130 function of $0.3 \mathrm{~Hz}$ was used to multiply all FIDs. After acquisition, all spectra were

131 manually phased and baseline corrected using the software MestReNova ${ }^{\circledR}$ (version

132 2.1.8-11880, MestreLab, Spain). Finally, spectra were calibrated to the chemical shift of

133 TSP $(\delta 0.00)$. In order to facilitate metabolite identification based on literature, a series

134 of 2D spectra on selected samples were acquired using correlation spectroscopy (COSY)

135 NMR spectroscopy.

136

$137 \quad$ 3.3. Statistical analysis

138 All spectra were scaled on unit variance and mean centered prior to analysis. To

139 evaluate metabolic variation between samples, principal component analysis (PCA) was

140 used. Orthogonal projection to latent structure discriminant analysis (O-PLS-DA) was

141 also performed, where ${ }^{1} \mathrm{H}-\mathrm{NMR}$ spectra were used as a matrix of independent variables

$142(\mathrm{X})$ and time or antibiotic concentration were used as prediction vectors (Y) to capture

143 the metabolic variations linear to time and antibiotic concentration. O-PLS DA models

144 were generated between each tiamulin concentration at every time point

145 independently. A heat map was generated using each of this model strength in order to 
146 visualize when tiamulin impacted bacterial metabolism in comparison to control and if

147 clusters related to dose could be observed.

148

\section{3. Results}

\section{$150 \quad$ 3.1. Modifications of B. pilosicoli metabolism during growth}

151 The aim of this study was to characterize B. pilosicoli metabolism under optimum

152 growth conditions. Figure 1 presents B. pilosicoli growth and metabolic activity in broth

153 media. PC1, which captured 49\% of the metabolic variation, indicated that a significant

154 metabolic shift was recorded after $96 \mathrm{~h}$ of incubation. Distinctions between $0 \mathrm{~h}, 24 \mathrm{~h}$

155 and $48 \mathrm{~h}$ were observed on the 3rd component, representing only $9 \%$ of the total

156 variation, which suggests a modest effect on the composition of the culture medium

157 over the first $48 \mathrm{~h}$. This metabolic trajectory indicates that bacterial metabolism might

158 change depending on the growth phase (Figure 1A and B). Scores from the same time

159 point were clustered together indicating good reproducibility of the experiment.

160 In the antibiotic free culture medium, the growth of B. pilosicoli was associated with a

161 decrease in glucose and an increase in amino acids (phenylalanine, alanine, tyrosine,

162 lysine, valine and methionine), fermentation products (lactate, acetate, butyrate and

163 isovalerate), as well as other compounds involved in the regulation of cell osmosis such

164 as myo-inositol and trimethylamine (TMA) as observed in the PCA results presented in

165 Figures $1 \mathrm{~A}$ and $\mathrm{C}$.

166 Glucose was the only readily identifiable substrate that showed a reduction over time

167 (Figure 1C). Decreased concentration of other substrates could not be detected and it is 168 possible that some may be below the detection limit of the NMR instrument. 169 Nevertheless, it is not unreasonable to assume that glucose was the only carbon source 170 used for bacterial anabolism and growth. B. pilosicoli and more especially the strain 
171 used for this experiment (B2904) is able to use a wide range of carbohydrates and

172 hexoses as primary carbon sources [10] but it would seem in this study that glucose was 173 used preferentially.

174

175

\subsection{Tiamulin impacts B. pilosicoli growth even at very low doses}

176 Having characterized the metabolic footprint of $B$. pilosicoli when grown in optimal 177 conditions, we then challenged it with increasing tiamulin doses. Tiamulin impacted $B$. 178 pilosicoli's growth at the lowest concentrations tested $(0.008$ and $0.016 \mu \mathrm{g} / \mathrm{mL})$ as 179 displayed in Figure 2. For these two doses, the bacterial count observed at the 180 stationary phase was one log lower than for the control demonstrating the ability of 181 tiamulin to reduce the growth of $B$. pilosicoli at low concentrations. Up to 54 hours, 182 growth curves of the two lowest concentrations $(0.008$ and $0.016 \mu \mathrm{g} / \mathrm{mL})$ were 183 identical to the control (T1 and T2 on the graph) but they stopped growing shortly after 184 and entered into the stationery phase. No bacterial growth was detected for higher 185 tiamulin concentrations (over $0.032 \mu \mathrm{g} / \mathrm{mL}$ ) confirming its efficiency to stop bacterial 186 proliferation. Interestingly, no gradual tiamulin dose response of bacterial growth was 187 observed. Indeed, growth rates were similar for the two lowest concentrations $(0.008$ 188 and $0.016 \mu \mathrm{g} / \mathrm{mL}$ ) while higher doses induced a complete inhibition of $B$. pilosicoli's 189 growth.

\section{$191 \quad$ 3.3. Metabolic response of B. pilosicoli to tiamulin}

192 A clear metabolic response of B. pilosicoli to tiamulin could be observed when the 193 antibiotic dose exceeded to $0.032 \mu \mathrm{g} / \mathrm{mL}$. At lower doses (0.008 and $0.016 \mu \mathrm{g} / \mathrm{mL})$,

194 although B. pilosicoli growth was decreased by 1 log (Figure 2) compared with 
195 untreated control, the metabolic trajectories remained unaffected (Figure 3A, 196 Supplemental Fig.1 and 2).

197 When bacteria were exposed to $0.032 \mu \mathrm{g} / \mathrm{mL}$ of tiamulin (Supplemental Fig. 3), a 198 disruption of the metabolic trajectory was observed which was due to modifications of 199 amino acid concentration. A noticeable increase of tyrosine, methionine, valine, 200 phenylalanine and lysine into the medium from 0 to $96 \mathrm{~h}$ was observed. After that time, 201 their concentration reduced, indicating consumption of these amino acids until the end 202 of the experiment. After $120 \mathrm{~h}$ of growth, the metabolic composition of the media was 203 comparable to control, indicating the full recovery of the metabolism following 204 antibiotic exposure.

205 Higher doses of tiamulin $(0.062$ and $0.125 \mu \mathrm{g} / \mathrm{mL})$ induced similar responses to those 206 observed at $0.032 \mu \mathrm{g} / \mathrm{mL}$ (Figure 3A and Supplemental Fig. 4. A and B). Amino acid 207 metabolism was affected in a greater extent.

208 At the maximum dose tested $(0.250 \mu \mathrm{g} / \mathrm{mL})$ the metabolic trajectory observed for the 209 media was drastically modified in comparison to those described previously (Figure 3 210 and Supplemental Fig. 5). The metabolic trajectory followed a circular shape where the 211 scores of the samples collected after $120 \mathrm{~h}$ of bacterial growth were clustered with the 212 ones observed at T0, indicating metabolic similarities with the baseline time-point. 213 Once again, amino acids were released into the medium as well as butyrate and myo214 inositol.

\section{3.4. B. pilosicoli survives post-antibiotic exposure}

217 To evaluate the surviving potential of B. pilosicoli after tiamulin exposure, samples from 218 replication of the growth curve experiment were plated on agar plate at the end of the 219 antibiotic challenge (120 h). For all tiamulin doses applied it was possible to observe $B$. 
220 pilosicoli colony formation on agar plates (Supplement Table 1). These results indicate

221 that B. pilosicoli is able to recover from tiamulin exposure (even at the highest dose of

$2220.250 \mu \mathrm{g} / \mathrm{mL}$ ) once back in optimal growth conditions.

223

\section{4. Discussion}

225 The results obtained from $B$. pilosicoli growth in a control medium without tiamulin 226 provide new insights about its general metabolism. The bacteria were able to produce 227 lactate and acetate from glucose fermentation without secreting methanol, suggesting 228 the use of the bifidum pathway according to the following equation: glucose $\rightarrow 3$ acetate $229+2$ lactate [30]. However, lactate was generally found in very small quantity in 230 comparison to acetate, indicating its potential use in other metabolic reactions. Bacteria 231 were also able to secrete butyric acid but not propionic acid. Both of these short chain 232 fatty acids were found to be potential carbon sources for B. pilosicoli [10]. Bacteria also 233 released a large number of amino acids that could be caused either by synthesis and 234 active secretion of these amino acids, or more likely due to exogenous protein 235 degradation. This result is in accordance with the genetic results published by Mappley et al. [10] that indicated a strong proteolytic capacity of the bacterium. This specific strain of B. pilosicoli was also shown to be able to use amino acids as primary carbon source [10]. However, as the bacterium favors glucose if available as primary carbon source, amino acids may here only be used for protein synthesis and may therefore become in excess in the culture medium where they accumulate. Finally, the bacteria secreted TMA. Gut bacteria generally produce TMA from dietary L-carnitine, betaine or

242 choline. Yet, it was not possible to detect a decrease in concentration of these compounds indicating that B. pilosicoli might not use these molecules as precursors or

244 that the technique used was not sensitive enough to detect such variations. 
245 More importantly, this work confirmed tiamulin ability to significantly reduce at very

246 low doses (0.008 and $0.016 \mu \mathrm{g} / \mathrm{mL})$ and inhibit at higher concentrations B. pilosicoli

247 growth. Decreased growth rate at such low antibiotic doses were unexpected, as

248 previous evaluation of minimum inhibitory concentration (MIC) values for this specific

249 strain were of $0.250 \mu \mathrm{g} / \mathrm{mL}$ [31], furthermore, $10-15 \%$ of $B$. pilosicoli isolates presented

250 MICs $>4 \mu \mathrm{g} / \mathrm{mL}$ [31]. Differences in the MIC values can be explained by experimental

251 conditions. Growth curves were acquired when B. pilosicoli was grown in BEB media

252 rather than on agar plates for MIC tests. The B. pilosicoli strain B2904 used in this study

253 is known to have an MIC of $0.250 \mu \mathrm{g} / \mathrm{mL}$ [31,32] but showed clear inhibition of growth

254 with concentrations below this value. Thus, our findings confirm the previously

255 reported observation that lower tiamulin MIC values are generally found in broth

256 compared to agar for B. hyodysenteriae [33].

257 Despite these encouraging results regarding tiamulin efficiency to inhibit pathogen

258 growth, the evaluation of $B$. pilosicoli metabolic viability in response to antibiotic

259 treatment revealed that classic MIC calculations might not be sufficient to assess

260 antibiotic efficiency. Indeed, B. pilosicoli metabolic rate reduction did not mirror

261 previously commented reduced growth rate in response to tiamulin treatment. At the

262 two lowest doses used (0.008 and $0.016 \mu \mathrm{g} / \mathrm{mL})$, B. pilosicoli growth was reduced by

263 one log in comparison to control. However, the metabolic trajectories observed by the

264 media were identical. Indicating that tiamulin was able to impact growth but that $B$.

265 pilosicoli basic metabolism remained unaffected. Higher doses were able to reduce but

266 not silent B. pilosicoli metabolism despite complete growth inhibition. Furthermore, the

267 metabolism of $B$. pilosicoli appears to slightly recover from all tiamulin concentrations

268 except from $0.250 \mu \mathrm{g} / \mathrm{ml}$ after $120 \mathrm{~h}$ of growth. This might be due to the apparition of

269 resistance, which is known as being a slow bacterial development process [34,35]. 
In addition, it was demonstrated that B. pilosicoli was able to survive post-tiamulin

271 exposure even at the highest antibiotic dose when plated on agar (after $120 \mathrm{~h}$ drug 272 exposure). Indeed B. pilosicoli colonies were identified $48 \mathrm{~h}$ after the end of the 273 antibiotic treatment for all doses tested $(0.008-0.250 \mu \mathrm{g} / \mathrm{mL})$. These results illustrate 274 the potential of $B$. pilosicoli to enter a dormancy state when exposed to tiamulin that is 275 reversible once the treatment period is over.

276 Besides, results demonstrated a slow response of the bacteria to antibiotic treatment as 277 modification of the metabolic footprint was only observed after more than $48 \mathrm{~h}$ of 278 growth in presence of tiamulin. From these results, it seems that metabolism was 279 stressed during the exponential phase, when bacterial division is compromised. 280 Metabolism modification was mainly associated with increased amino acid 281 consumption (that were produced in the control). However, as the provenance of these amino acids remains unclear, two hypotheses can be formulated. Firstly, in response to 283 antibiotic stress bacteria could use amino acids as alternative energy substrates. 284 Secondly, B. pilosicoli might not be able to hydrolyse proteins present in the media 285 because new protein synthesis, such as secreted proteases, is blocked at the ribosome. The specificity of the amino acids used indicates the first option is the most probable and that catabolism repression could be overridden to secure energy from multiple sources. This is an interesting hypothesis that needs confirmation by alternative techniques such as transcriptomics.

290 The fact that B. pilosicoli remain viable and metabolically active without dividing despite 291 the antibiotic treatment and is able to recover after antibiotic exposure could partly explain the IS relapse observed in farms after tiamulin intervention. Indeed, it seems to 293 arise from these results that bacteria remain viable but are not able to divide entering 294 therefore a dormancy stage. It is highly possible that such phenomenon occurs in the 
295 intestinal lumen, where bacteria could suffer from inactivation of cell division but 296 remain viable. This bacterial state might be associated with a decrease in their 297 pathogenicity explaining the disappearance of associated symptoms. Nevertheless, 298 bacteria might remain viable but at a "dormancy" state in the intestinal lumen or animal 299 faeces until the environment becomes less hostile (end of antibiotic treatment) when 300 they can recover their pathogenic property. However, it is impotent to point out that 301 here B. pilosicoli was recovered on agar plates that represent optimal growth 302 conditions. This might not be the case in the intestinal lumen that is a more hostile environment when the bacterium also needs to compete with other commensal bacteria

304 and is confronted to the host's immune system.

305 As increasing antibiotic resistance mechanisms developed by pathogenic bacteria are 306 arising, many studies and reviews have stressed the concerns linked to inappropriate antibiotic usage. Indeed, this is strongly linked to development of antibiotic resistance, a burden for health and industry. There is therefore a surge for redefining appropriate antibiotic use that would help minimizing the current concern linked to decreased antibiotic efficiency. Thus, importance should be given to new methods development aiming at better assessing antibiotic efficiency and to detect potential antibiotic

312 resistance factor development. This study indicates that metabonomics could be and easy and practical way to evaluate bacterial metabolic activity and therefore assess antibiotic efficiency to totally inactivate pathogens and therefore avoid infection relapse.

\section{Conclusion}

This work gave a clearer understanding of B. pilosicoli metabolism in optimum growth conditions, including indication regarding favored fermentation pathways and amino 
acids metabolism. It supports the fact that tiamulin can inhibit efficiently bacterial

321 growth at low concentrations. However, it was surprising to observe that tiamulin could

322 impact B. pilosicoli growth without influencing its basic metabolism. It also reveals that

323 the bacterium try to maintain metabolic homeostasis despite an obvious stress visible

324 on the growth curve, demonstrating that in response to xenobiotic stress, bacterial

325 division is the first mechanism to be suspended. This indicates that tiamulin might

326 present a good solution against AIS outbreaks, as it is able to significantly reduce or stop

327 bacterial growth, provided that the efficient dose is achieved in the gut of every

328 individual. Even so, the treatment may not be sufficient to avoid relapse of the disease.

329 Such findings suggest that measurement of bacterial activity might be needed in order

330 to assess antibiotic efficiency against potential reoccurrence of the disease. In that prospect, metabonomics appeared as a potential solution to evaluate if antibiotic treatment can inactivate microbial metabolic activity.

\section{References}

335 [1] Stanton, T. B. \& Hampson, D. J. Physiology of Ruminal and intestinal spirochaetes.

[2] Duhamel, G. E., Stryker, C. J., Lu, G., Wong, V. J. \& Tarara, R. P. Colonic spirochetosis of colony-raised rhesus macaques associated with Brachyspira and Helicobacter. Anaerobe. 9, 45-55 (2003).

[3] Hidalgo, A., Rubio, P., Osorio, J. \& Carvajal, A. Prevalence of Brachyspira pilosicoli and 'Brachyspira canis' in dogs and their association with diarrhoea. Vet. Microbiol. 146, 356-60 (2010).

[4] Trott, D. J., Stanton, T. B., Jensen, N. S., Duhamel, G. E., Johnson, J. L., \& Hampson, D. J. Serpulina pilosicoli sp., the agent of porcine intestinal spirochetosis. Int. J. Syst. Bacteriol. 46, 206-15 (1996).

[5] Naresh, R. \& Hampson, D. J. Attraction of Brachyspira pilosicoli to mucin. Microbiology. 156, 191-7 (2010).

[6] Hopwood, D., Pethick, D. \& Hampson, D. Increasing the viscosity of the intestinal 
contents stimulates proliferation of enterotoxigenic Escherichia coli and Brachyspira pilosicoli in weaner pigs. Br. J. Nurition. 88, 523-532 (2007).

351

352

353

354

355

356

357

358

359

360

361

362

363

364

365

366

367

368

369

370

371

372

373

374

375

376

377

378

379

380

381

382

383

384

[7] Prapasarakul, N., Lugsomya, K., Disatian, S., Lekdumrongsak, T., Banlunara, W., Chetanachan, P., \& Hampson, D. J. Faecal excretion of intestinal spirochaetes by urban dogs, and their pathogenicity in a chick model of intestinal spirochaetosis. Res. Vet. Sci.91, e38-43 (2011).

[8] Li, C., Motaleb, A., Sal, M., Goldstein, S. F. \& Charon, N. W. Spirochete periplasmic flagella and motility. J. Mol. Microbiol. Biotechnol. 2, 345-54 (2000).

[9] Dworkin, M. The prokaryotes: Vol. 7: Proteobacteria: Delta and Epsilon Subclasses. S. Falkow, E. Rosenberg, K. H. Schleifer, \& E. Stackebrandt (Eds.). Springer Science \& Business Media. 2006.

[10] Mappley, L. J., Black, M. L., AbuOun, M., Darby, A. C., Woodward, M. J., Parkhill, J., Turner, A. K., Bellgard, M. I., La, T., Philips, N. D., La Ragione, R. M. \& Hampson, D. J. Comparative genomics of Brachyspira pilosicoli strains: genome rearrangements, reductions and correlation of genetic compliment with phenotypic diversity. BMC Genomics. 13, 454 (2012).

[11] Dassanayake, R. P. Biochemical properties of membrane-associated proteases of Brachyspira pilosicoli isolated from humans with intestinal disorders. J. Med. Microbiol. 53, 319-323 (2004).

[12] Nakamura, S., Adachi, Y., Goto, T. \& Magariyama, Y. Improvement in Motion Efficiency of the Spirochete Brachyspira pilosicoli. Biophys. J. 90, 3019-3029 (2006).

[13] Fellström, C. \& Gunnarsson, A. Phenotypical characterisation of intestinal spirochaetes isolated from pigs. Res. Vet. Sci. 59, 1-4 (1995).

[14] Duhamel, G. E., Hunsaker, B. D., Mathiesen, M. R., \& Moxley, R. A. Intestinal spirochaetosis and giardasis in a beagle pup with diarrhoea. Vet. Pathol. 33, 360362 (1996)

[15] Taylor, D. J., Simmons, J. R. \& Laird, H. M. Production of dirrhoea and dysentery in pigs by feeding pure cultures of spirochaete differing from Treponemu hyodysenteriae. Vet. 106, 326-332 (1980).

[16] Johnston, W. T., Dewey, C. E., Friendship, R. M., Smart, N., McEwen, B. J., Stalker, M., \& de Lange, C. F. An investigation of the etiology of a mild diarrhea observed in a group of grower/finisher pigs. Can. Vet. J. 42, 33-37 (2001).

[17] Wilberts, B. L., Arruda, P. H., Warneke, H. L., Erlandson, K. R., Hammer, J. M., \& Burrough, E. R. Cessation of clinical disease and spirochete shedding after tiamulin treatment in pigs experimentally infected with 'Brachyspira hampsonii'. 
Res. Vet. Sci. 97, 341-347 (2014).

386

387

388

389

390

391

392

393

394

395

396

397

398

399

400

401

402

403

404

405

406

407

408

409

410

411

412

413

414

415

416

417

418

419

420

[18] Burch, D. Tiamulin activity against Brachyspira hyodysenteriae. Vet. Rec. 163, 698 (2008).

[19] Burch, D. \& Klein, U. Treatment of Brachyspira species with high MICs against Tiamulin in layers. 6th Int. Conf. Avian Intest. Spyrochaetosis Infect. Anim. Humans. 51 (2013).

[20] Stephens, C. P. \& Hampson, D. J. Evaluation of tiamulin and lincomycin for the treatment of broiler breeders experimentally infected with the intestinal spirochaete Brachyspira pilosicoli. Avian Pathol. 31, 299-304 (2002).

[21] Burch, D. G. S., Harding, C., Alvarez, R. \& Valks, M. Treatment of a field case of avian intestinal spirochaetosis caused by Brachyspira pilosicoli with tiamulin. Avian Pathol. 35, 211-6 (2006).

[22] Schlünzen, F., Pyetan, E., Fucini, P., Yonath, A. \& Harms, J. M. Inhibition of peptide bond formation by pleuromutilins: the structure of the $50 \mathrm{~S}$ ribosomal subunit from Deinococcus radiodurans in complex with tiamulin. Mol. Microbiol. 54, 12871294 (2004).

[23] Poulsen, S. M., Karlsson, M., Johansson, L. B., \& Vester, B. The pleuromutilin drugs tiamulin and valnemulin bind to the RNA at the peptidyl transferase centre on the ribosome. Mol. Microbiol. 41, 1091-1099 (2001).

[24] Long, K. S., Hansen, L. H., Jakobsen, L. \& Vester, B. Interaction of pleuromutilin derivatives with the ribosomal peptidyl transferase center. Antimicrob. Agents Chemother. 50, 1458-1462 (2006).

[25] Forschungsinstitut, S. The Mode of action of pleuromutilin derivatives effect on cell-free polypeptide synthesis. Europ. J. Biochem. 533, 527-533 (1974).

[26] Stephens, C. P. \& Hampson, D. J. Evaluation of tiamulin and lincomycin for the treatment of broiler breeders experimentally infected with the intestinal spirochaete Brachyspira pilosicoli. Avian Pathol. 31, 299-304 (2002).

[27] Burch, D. G. S., Harding, C., Alvarez, R. \& Valks, M. Treatment of a field case of avian intestinal spirochaetosis caused by Brachyspira pilosicoli with tiamulin. Avian Pathol. 35, 211-6 (2006).

[28] Sperling, D., Smola, J. \& Cízek, A. Characterisation of multiresistant Brachyspira hyodysenteriae isolates from Czech pig farms. Vet. Rec. 168, 215 (2011).

[29] Karlsson, M., Aspan, A., Landén, A., \& Franklin, A. Further characterization of porcine Brachyspira hyodysenteriae isolates with decreased susceptibility to tiamulin. J. Med. Microbiol. 53, 281-285 (2004).

[30] Nicholson, J. K., Lindon, J. C. \& Holmes, E. 'Metabonomics': understanding the 
metabolic responses of living systems to pathophysiological stimuli via multivariate statistical analysis of biological NMR spectroscopic data. Xenobiotica. 29, 1181-9 (1999).

[31] Mappley, L. J., Tchórzewska, M. a, Cooley, W. a, Woodward, M. J. \& La Ragione, R. M. Lactobacilli antagonize the growth, motility, and adherence of Brachyspira pilosicoli: a potential intervention against avian intestinal spirochetosis. Appl. Environ. Microbiol. 77, 5402-5411 (2011).

[32] Gottschalk, G. Bacterial metabolism. Springer Science \& Business Media. (2012).

[33] Pringle, M., Landén, A., Unnerstad, H. E., Molander, B. \& Bengtsson, B. Antimicrobial susceptibility of porcine Brachyspira hyodysenteriae and Brachyspira pilosicoli isolated in Sweden between 1990 and 2010. Acta Vet. Scand. 54, 54 (2012).

[34] Woodward, M. J., Mappley, L., Le Roy, C., Claus, S. P., Davies, P., Thompson, G., \& La Ragione, R. M. Drinking water application of Denagard® Tiamulin for control of Brachyspira pilosicoli infection of laying poultry. Res. Vet. Sci. 103, 87-95 (2015).

[35] Rohde, J., Kessler, M., Baums, C. G. \& Amtsberg, G. Comparison of methods for antimicrobial susceptibility testing and MIC values for pleuromutilin drugs for Brachyspira hyodysenteriae isolated in Germany. Vet. Microbiol. 102, 25-32 (2004).

[36] Bock, A., Turnowsky, F., Hogenauer, G., Universitat, M. D. \& Germany, W. Tiamulin resistance mutations in Escherichia coli. J. Bacteriol. 151, 1253-1260 (1982).

[37] Karlsson, M., Gunnarsson, A. \& Franklin, A. Susceptibility to pleuromutilins in Brachyspira (Serpulina) hyodysenteriae. Anim. Heal. Res. Rev. 2, 59-66 (2001).

\section{Figures and tables}

Figure 1: B. pilosicoli consumed glucose and released amino acids and fermentation products in its environment. (A) PCA scores plot. (B) B. pilosicoli growth curve in Brachyspira enrichment broth media under anaerobic conditions made in triplicate. (C) Associated loadings of the first component. The metabolic trajectories described by the arrows were determined by the position of the centroids calculated at each time point using the coordinate of the associated scores on the principal components. 
454 Figure 2: Impact of tiamulin on B. pilosicoli growth in Brachyspira enrichment broth 455 media under anaerobic conditions. Growth was measured in triplicate every $2 \mathrm{~h}$ for 120 456 h.

458 Figure 3: (A) Metabolic trajectories derived from the PCA analysis performed using all 459 the sample population $(\mathrm{N}=252)$ of the study (i.e. control plus 6 tiamulin dilution) on PC1 460 and PC3 displaying the centroids for each time points of the control and three 461 concentrations of tiamulin. (B) Heat map representing the O-PLS DA model strength 462 existing between each tiamulin concentration at each time point, based on $\mathrm{R}^{2} \mathrm{Y}$ 463 (goodness of fit of the model) and $\mathrm{Q}^{2} \mathrm{Y}$ (goodness of prediction of the model) values 464 using the following formula: Model strength $=\frac{R^{2} Y \times Q^{2} Y}{R^{2} Y-Q^{2} Y}$.

\section{Supplemental material}

Supplement Fig. 1: Metabolic trajectories of B. pilosicoli footprints in broth media for $120 \mathrm{~h}$ at a tiamulin concentration of: $0.008 \mu \mathrm{g} / \mathrm{mL}(\mathrm{A})$ and $0.016 \mu \mathrm{g} / \mathrm{mL}(\mathrm{B})$. The arrows

470 indicate the metabolic trajectory. The metabolic trajectories described by the arrows were determined by the position of the centroids calculated at each time point using the

472 coordinate of the associated scores on the PCs.

474 Supplement Fig. 2: Metabolic variation related to PCA scores plots presented in 475 Supplement Fig. 1. (A) loadings of the principal component 1 of the model presented in 476 Fig A.1.A. (B) loadings of the principal component 3 of the model presented in 
477 Supplement Fig. 1.A. (C) loadings of the principal component 1 of the model presented

478 in Supplement Fig. 1.B. (D) loadings of the principal component 4 of the model 479 presented in Supplement Fig. 1.B.

480

481 Supplement Fig. 3: Metabolic trajectories of B. pilosicoli footprint in broth media for 120

$482 \mathrm{~h}$ at a tiamulin concentration of $0.032 \mu \mathrm{g} . \mathrm{ml}$ on principal component 1 and 3. (A) PCA

483 score plot. (B) Associated loading plot for PC1. The metabolic trajectories described by

484 the arrows were determined by the position of the centroids calculated at each time 485 point using the coordinate of the associated scores on the PCs.

486

487 Supplement Fig. 4: Metabolic trajectories of B. pilosicoli footprint in broth media for 120

$488 \mathrm{~h}$ at a tiamulin concentration of: $0.062 \mu \mathrm{g} / \mathrm{ml}(\mathrm{A})$ and $0.125 \mu \mathrm{g} / \mathrm{ml}(\mathrm{B})$. The arrows 489 indicate the metabolic trajectory. The metabolic trajectories described by the arrows were determined by the position of the centroids calculated at each time point using the coordinate of the associated scores on the PCs.

492

493 Supplement Fig. 5: Metabolic trajectories of B. pilosicoli footprint in broth media for 120 $494 \mathrm{~h}$ at a tiamulin concentration of $0.250 \mu \mathrm{g} / \mathrm{ml}$. (A) PCA score plot. (B) Associated loading 495 plot of PC1. The arrows indicate the metabolic trajectory. The metabolic trajectories 496 described by the arrows were determined by the position of the centroids calculated at each time point using the coordinate on the associated scores on the PCs.

Supplement Tab. 1: Growth scores of B. pilosicoli on agar plate post-antibiotic exposure.

500 Detection of $B$. pilosicoli's growth $48 \mathrm{~h}$ after plating are indicated by a sign '+' and by '-' if 501 no growth was observed. 